\title{
America's Two Worlds of Welfare: Subnational Institutions and Social Assistance in Metropolitan America
}

\author{
Margaret Weir and Jessica Schirmer
}

\begin{abstract}
Studies of the "delegated state" highlight the growing role of nongovernmental organizations to fulfill public purposes. We argue that America's delegated state has taken two distinct forms: a civic-public model prominent in the North and Midwest and a very different religious-private model more evident in the South and the West. Distinctive regional legacies rooted in European immigration, religion, race, and the timing of urban growth gave rise to diverse organizational configurations for assisting the poor in different parts of the country. As a consequence, the institutions for assisting the poor are weaker in the growing regions of the South and Mountain West.
\end{abstract}

$\Lambda$ midst the noise of the 2016 presidential campaign, Republican House Speaker Paul Ryan ventured from the Capitol across the Anacostia River to announce a new poverty plan that promised to promote upward mobility. Appearing at House of Help City of Hope, a prominent nonprofit organization that builds affordable housing and provides social services to the poorest ward in the District of Columbia, the Speaker praised the work of nonprofit organizations and called for increasing the role of these organizations in the fight against poverty.

There was nothing new about Ryan's celebration of nonprofit organizations. Americans have long relied on nongovernmental organizations to deliver social benefits to the needy. A large literature documents the growth of the "third sector" that has made nonprofit organizations key arms of the American welfare state. ${ }^{2}$ In this narrative, charitable organizations multiplied during the Progressive era as Protestant elites sought to assist - and improve — the immigrant poor. Immigrants reacted by establishing their own organizations to reflect their religious beliefs. In the 1960s and 1970s, a new public-nonprofit mix crystalized as religiously sponsored charitable organizations benefited from the vast expansion in federal social spending. ${ }^{3}$ In return, they accepted civic norms, including prohibitions on proselytizing. At the same time, the War on Poverty injected new life into the nonprofit sector by supporting

${ }^{*}$ Data replication sets are available in Harvard Dataverse at: https://doi.org/10.7910/DVN/4S83QX

Margaret Weir is Wilson Professor of Political Science and International and Public Affairs at Brown University (margaret_weir@brown.edu). Herwork focuses on social policy, federalism, and local politics in the United States. She is currently working on a book about the politics of spatial inequality in American metropolitan areas. Jessica Schirmer is a Doctoral Candidate in the Department of Sociology at the University of California, Berkeley

(jess.schirmer@berkeley.edu). Her dissertation is on federal housing policy and private rental housing from the New Deal to the present.

The authors would like to thank the four anonymous reviewers for Perspectives on Politics. Neil Bradford, Andrea Campbell, Cybelle Fox, Candelaria Garay, David Karol, Desmond King, Damon Mayrl, Michael McQuarrie, Susan Moffitt, Rolf Pendall, Sarah Reckhow, Wendy Schiller, Daniel Schneider, Hilary Silver, Peter Trubowitz, Jason Wittenberg, and Nick Ziegler provided helpful advice and comments. The authors also received valuable feedback from seminar and conference participants at the London School of Economics; Harvard; the University of Maryland; the University of Pittsburgh; the American, Canadian, and British Political Development 2016 meeting, the Midwest Political Science Association 2016 meetings, and the American Political Science Association 2017 meetings. They thank John Towey, Elizabeth Mattiuzzi, and Manuel Monti-Nussbaum for expert research assistance. The authors gratefully acknowledge the support of the McArthur Foundation Network on Building Resilient Regions. 
innovative organizations to mobilize and serve poor communities of color. During the 1970s and 1980s nonprofits rose in significance as the federal government devolved social services to states and localities and shed responsibility for building public housing. After the 1996 welfare reform legislation restricted cash assistance, the human services delivered by nonprofits took on greater importance. ${ }^{4}$

Hailed as a distinctively American response to social change and economic need, this "delegated state" has also faced criticism in recent years as a method for implementing policies deemed neoliberal. ${ }^{5}$ Critics charge that publicprivate arrangements bend public purposes to serve private ends, mask retrenchment, and deny beneficiaries access to critically important public benefits. ${ }^{6}$ The increasingly neoliberal cast of federal social policy-embodied in reduced benefits and new market-oriented criteria for administration-not only exacerbates the failings of nongovernmental organizations in this view, it also opens the door to for-profit firms and unchecked rent seeking in the administration of social policy.

The historical narrative that traces the rise of publicprivate social provision emphasizes the developments of the North and Midwest, where these arrangements first took shape. Although researchers recognize that the nonprofit infrastructure varies across metropolitan areas, the nature, implications, and causes of such variation remain unclear. While studies of bottom-up organizational creativity expect the laggards to catch up, studies of top-down retrenchment see success as the exception, not the rule. Moreover, some argue that the supply of resources and personnel needed to create nonprofits is key while others contend that the demand for nonprofits is what matters.

We argue here that distinct historical legacies rooted in race, religion, and European immigration, and in the timing of urban growth gave rise to diverse organizational configurations for assisting the poor in different parts of the country. As a consequence, the delegated state has taken on two distinct forms in America: a civic-public model prominent in the North and Midwest and a very different religious-private model more evident in the South and the Mountain West, with the Pacific Coast exhibiting a diverse pattern depending on the timing of urban growth. ${ }^{8}$ The civic-public model, we show, provides a much more congenial setting for nonprofit organizations that serve low-income communities.

These regional differences mean that the organized resources for assisting the poor vary systematically in different parts of the country. In the South and Mountain West, nonprofits have fewer resources for buffering federal cuts and advocating against funding reductions; at the same time, they are more vulnerable to competition from for-profit service providers. Communities in the North and Midwest with robust organizational ecologies have more capacity to mount political challenges to cutbacks in public funding and to limit the growth of for-profit competitors.

To understand these institutional differences and assess future trajectories, we first consider what we know about variation in the subnational welfare state, emphasizing the importance of understanding the distinctive ways in which civil society and the delegated state co-evolved in different parts of the country. We then examine the critical role of four factors that have since the Progressive era created distinctive regional patterns: European immigration, religion, race, and the timing of urbanization. To test whether these patterns persist into the present, we draw on data from the National Center for Charitable Statistics and the census to present a Metropolitan Institutional Support Index that identifies the distinct organizational configurations of public, private, and nonprofit assistance to the poor in metropolitan areas in different parts of the country. The final section of the article considers the future trajectories of the two models in different regions of the country. We conclude by assessing the implications of these findings for the bottom-up federalism of the delegated state.

\section{America's Subnational Welfare State}

The decentralization of social benefits and the turn to nonstate providers has provoked a surge of interest in the subnational dynamics of welfare states. ' Efforts to understand how states and local governments have approached their social policy responsibilities have tracked and explained variations in spending on benefit programs across the states. ${ }^{10}$ One of the central findings of this literature is the correlation between race and spending. States with larger numbers of African Americans and Latinos exhibit lower levels of spending for social welfare. ${ }^{11}$

There is no doubt that state spending levels provide one crucial indicator of variation in social benefits-for both entitlement programs and social services. By recent estimates, human service nonprofit organizations derive 65 percent of their revenue from public dollars. ${ }^{12}$ After the federal government devolved and cut federal social programs during the 1980 s, states not only acted as pass-throughs for federal dollars, they also took on greater responsibility for benefit levels in key programs. ${ }^{13}$ The federal government allows states exceptional leeway in devising programs for the poor as authors including Bruch, Meyers, and Gornick observe. ${ }^{14}$ Examining eleven core safety net programs for which states and the federal government share responsibility, they find that programs where states have the greatest authority exhibit the most variation. Local governments spend far less on redistributive purposes but even these small amounts can provide important sources of nonprofit income. ${ }^{15}$ 
But, we suggest, spending represents only a piece of the puzzle. The organizational infrastructure for serving the poor also varies on several other critical dimensions that determine the scope of social programs, their accessibility, and the politics that surround them. By themselves, spending patterns do not tell us enough about the configuration of public and private institutional relationships that organize the politics and delivery of public benefits for low-income people. As Esping-Andersen's classic comparison of national welfare states shows, institutional relationships anchored in distinct political and social connections can create policy variation even within similar levels of spending. ${ }^{16}$ Moreover, as institutionalist theorists argue, configurations of institutions and ideas can work to reinforce one another over time, so that spending may itself be influenced by institutional arrangements. ${ }^{17}$

We argue that the delegated state should be seen as a set of organizational relationships that co-evolve as governments and nongovernmental organizations grow and build relationships over time. ${ }^{18}$ This perspective, as articulated by Morgan and Orloff, sees states "as encompassing multiple institutions, varying forms of interpenetration with civil society, multiple scales of governance, and potentially contradictory logics." In a similar vein, Clemens characterizes the relationship between state and social organizations as symbiotic. ${ }^{19}$

Most configurative analyses of social policy take the nation-state as their focus. In these analyses, the United States represents a low-spending liberal model that outsources extensively to nonprofit organizations. ${ }^{20}$ But we know that sharp differences have characterized regions of the country since the Founding. On the eve of the New Deal, Cybelle Fox identified three worlds of welfare linked to distinct labor markets, political contexts, and racial systems. ${ }^{21}$ Scholars recognize that even the most politically assertive initiative of the Great Society, the War on Poverty, relied on local organizations to carry out federal goals. States and localities won greater autonomy in shaping social policy after the 1970s as the federal government devolved decision-making and reduced spending on programs that assist the poor. Have different paths of regional development in the United States created enduring distinctions in our approach to social welfare? Or have federal initiatives since the New Deal worked to lessen regional institutional variation?

We argue that federal policies have allowed regional differences to flourish by granting state and local governments extensive discretion in implementing assistance to the poor. After the 1960s, Washington moved away from what Desmond King calls a "forceful federalism" exemplified by the War on Poverty's categorical grants and vigilant monitoring of local implementation. ${ }^{22}$ The devolution and block granting of federal social policy in the 1970s combined with support for outsourcing in the late 1960s and for-profit privatization in the 1980s, gave state and local institutions broad leeway in how they chose to assist the poor. The 1996 welfare reform (Temporary Assistance to Needy Families or TANF), which replaced the federal entitlement to cash support with block grants to the states, further enhanced state and local discretion. ${ }^{23}$ TANF also magnified the importance of services as access to cash assistance became sharply limited. ${ }^{24}$ In the process, two very different local models for assisting low-income residents emerged.

The first, the civic-public model, features a robust nonprofit sector, strong local philanthropy, and close bonds between these civil society organizations and local governments. Large experienced nonprofit organizations rely on public funds and can expand their resources by applying for grants from governments as well as philanthropic foundations. For example, Reckhow shows that cities with more nonprofit organizations secure more federal grants than those without regardless of need. ${ }^{25}$ Similarly Lowry and Potoski show the central role that locally-based interest groups play in securing competitive grants. ${ }^{26}$ As we will see, many of these nonprofit organizations are religiously affiliated or have religious origins. But in accepting public funds, they enter the civic domain and abide by its rules, which prohibit proselytizing.

A robust nonprofit ecology is significant because it can defend or even expand public dollars targeted at low-income residents through organized advocacy. ${ }^{27}$ Scholars have long recognized the reciprocal relationships that can develop between nonprofits and government. ${ }^{28}$ Government funding can create vested interests that lobby to retain their funding when it is threatened; these interests may also engage in broader advocacy campaigns aimed at increasing the overall supply of resources. ${ }^{29}$ Studies show that many nonprofits engage in advocacy, either on their own or as part of broader coalitions. ${ }^{30}$

Philanthropy matters both because it provides financial resources for nonprofits, but also because it can serve as an organizational node for the nonprofit community. Community foundations and federated organizations such as the United Way play a special role in this regard since they have an explicit geographical mission. These organizations supply information, training, and organizational connections that build a community of expertise around human services and affordable housing. Their combination of geographic reach and information resources makes these organizations especially well situated to identifying new needs and helping to start new organizations to address them. ${ }^{31}$

The second model, the religious-private model, displays a significantly smaller nonprofit sector, weaker ties between government and nonprofits, and less robust philanthropic institutions. Instead, this configuration of institutions features a larger role for private religious charity and for-profit government contracting. Religious charity is an essential element of the safety net in all parts 
of the country. Yet it is no substitute for public funds. A wide literature has shown that congregations are inherently limited in the services they can provide. ${ }^{32}$ In the repeated waves of the National Congregations Study, sociologist Mark Chaves found that congregations tended to supply small-scale short-term emergency assistance. In 2012, only 14 percent of congregations surveyed had a staff person who devoted at least one-quarter of their time to social services. Only 4.9 percent had applied for a government grant in the past two years and only 8.9 percent reported starting a separate nonprofit for human services or ministerial outreach in the past two years. ${ }^{33}$

The religious-private model also relies more heavily on contracting with for-profit firms to deliver social services and affordable housing. A large presence of for-profit stakeholders creates a distinctive politics surrounding assistance to the poor. Since firms defend their own contracts, they are less likely to join broader coalitions of nonprofit social service providers to advocate against cuts or to press for additional public dollars. Because they need to make a profit, these contractors avoid entering less remunerative service functions, leaving these services with fewer political allies. For example, few private providers enter the field of serving the homeless mentally ill. ${ }^{34}$ The ties that for-profit contractors forge with governments are more narrow and particular than those built by nonprofits. In contrast to nonprofits, for-profits also do not attract philanthropy and do not allocate resources to help cross-subsidize less profitable but worthy activities. ${ }^{35}$ Inadequate contract design and weak government monitoring capabilities, which often accompany enthusiasm for contracting with for-profits, exacerbate the risk of rentseeking and cream skimming that abandons the least promising clients. ${ }^{36}$

Critical questions about the trajectories of social support in different metropolitan areas can only be understood by taking into account these distinct organizational configurations. How did they emerge? Will the nonprofit laggards come to resemble the leaders or are they following fundamentally different tracks? Even if spending increased, would significant differences endure across metros? Organizational configurations also provide leverage for understanding the justification and ideas that inform the politics of social welfare in different places. Finally, organizational relationships illuminate the challenges that external actors, such as the federal government or national philanthropic foundations, are likely to confront if they attempt to influence local capacities to implement social welfare programs.

\section{Varieties of Local Infrastructure Serving the Poor}

To investigate variation in the organizational configuration of social services and affordable housing programs, we first probe the historical development of social infrastructure for assisting the poor in different parts of the country, showing how the distinctive alchemy of European immigration, religion, race, and the timing of urbanization created divergent institutional legacies for assisting the poor. In the North and Midwest the civicpublic model thrived after the 1960s as increased federal spending combined with devolution of authority to states and localities and delegation to nongovernment organizations. In the South and Mountain West, a much weaker nonprofit infrastructure and a preference for assisting the poor through religious congregations constrained the civic role. The later timing of urbanization also meant that these jurisdictions increasingly turned to for-profit firms to deliver social programs. The organizationally and politically weaker civic infrastructure inherited from the past, together with the tremendous growth of these regions, has created a religious-private model of social assistance quite distinct from that in the North and Midwest.

Having documented these distinct patterns, we then test how these distinct historical legacies continue to exert influence by devising a Metropolitan Institutional Support Index. The Index ranks twenty-five metropolitan areas in different regions of the country on the public, civic, and private characteristics of the organizations that serve low-income residents. The metros are listed by region in table 1.

\section{The Roots of Regional Differences}

Institutional variations in support for the poor trace their roots to sharply distinct regional histories rooted in patterns of European immigration, religion, race, and the timing of urbanization. In the North and Midwest, European immigration, religious organizations, and government intertwined over time to create a virtuous cycle between robust civil society organizations and local political support for serving low-income residents. In the Pacific West, San Francisco, and to a lesser extent, Seattle, shared a similar history. By contrast, the South and the Mountain West, and other metros in the Pacific West exhibited very different patterns. In the South, the combination of low levels of immigration and legalized racial segregation constrained the development of civil-society organizations focused on the poor and sharply circumscribed the public sphere. Likewise in the Mountain West, limited European immigration, civic exclusion of Mexican migrants, and the political dominance of Anglo economic elites provided little impetus for developing civil-society organizations or a public sector focused on the poor. ${ }^{37}$

Comparative analyses of welfare states highlight the enduring impact of different religious traditions on the organization of social policy and its particular importance in programs that serve the poor. ${ }^{38}$ Religion shapes beliefs about when and how to assist the poor but it also provides 


\section{Table 1 Population five largest metros in five regions of the U.S, 2005-2009}

\begin{tabular}{|c|c|}
\hline & Pop. \\
\hline \multicolumn{2}{|l|}{ North } \\
\hline New York-Northern New Jersey-Long Island, NY-NJ-PA & $18,912,644$ \\
\hline Philadelphia-Camden-Wilmington, PA-NJ-DE-MD & $5,910,593$ \\
\hline Boston-Cambridge-Quincy, MA-NH & $4,513,934$ \\
\hline Pittsburgh, PA & $2,360,259$ \\
\hline Providence-New Bedford-Fall River, RI-MA & $1,602,591$ \\
\hline \multicolumn{2}{|l|}{ South } \\
\hline Dallas-Fort Worth-Arlington, TX & $6,144,234$ \\
\hline Houston-Baytown-Sugar Land, TX & $5,595,262$ \\
\hline Miami-Fort Lauderdale-Miami Beach, FL & $5,484,777$ \\
\hline Atlanta-Sandy Springs-Marietta, GA & $5,238,994$ \\
\hline Tampa-St. Petersburg-Clearwater, FL & $2,702,390$ \\
\hline \multicolumn{2}{|l|}{ Midwest } \\
\hline Chicago-Naperville-Joliet, IL-IN-WI & $9,461,816$ \\
\hline Detroit-Warren-Livonia, MI & $4,452,548$ \\
\hline Minneapolis-St. Paul-Bloomington, MN-WI & $3,202,412$ \\
\hline St. Louis, MO-IL & $2,827,601$ \\
\hline Cincinnati-Middletown, OH-KY-IN & $2,140,796$ \\
\hline \multicolumn{2}{|l|}{ Mountain West } \\
\hline Phoenix-Mesa-Scottsdale, AZ & $4,151,634$ \\
\hline Denver-Aurora, CO & $2,398,156$ \\
\hline Las Vegas-Paradise, NV & $1,821,507$ \\
\hline Salt Lake City, UT & $1,090,416$ \\
\hline Tucson, AZ & 990,213 \\
\hline \multicolumn{2}{|l|}{ Pacific West } \\
\hline Los Angeles-Long Beach-Santa Ana, CA & $12,762,126$ \\
\hline San Francisco-Oakland-Fremont, CA & $4,218,534$ \\
\hline Riverside-San Bernardino-Ontario, CA & 4,022,939 \\
\hline Seattle-Tacoma-Bellevue, WA & $3,306,836$ \\
\hline San Diego-Carlsbad-San Marcos, CA & $2,987,543$ \\
\hline Average & $4,732,030$ \\
\hline Standard Dev. & $3,940,170$ \\
\hline Min & 990,213 \\
\hline Max & $18,912,644$ \\
\hline
\end{tabular}

Source: U.S. Census Bureau, 2009a.

an organizational infrastructure that states can use as they build welfare systems. ${ }^{39}$ In national comparisons, the United States embodies the Calvinist beliefs that prize personal responsibility and view personal or religious charity as the best way to assist the poor. ${ }^{40}$ But the United States was a site of fierce religious competition that played out in state and local political arenas. This competition led to a variegated pattern of public religious relationships that supported a diverse set of organizations to assist the poor. As a consequence, regionally distinct religious patterns stemming from immigration had a profound impact on the infrastructure of support for the poor and its relationship to politics.

The intertwining of European immigration, religion, and government created a potent mix in the large cities of the North and Midwest. Competition between mainline Protestant elites and the largely immigrant Catholic and Jewish communities drove the creation of new organizations. Seeking to tame the social ills associated with large-scale immigration and to create services free from often-corrupt local machines, mainline Protestants established independent charitable organizations, such as Charity Organization Societies and later, community philanthropy. Immigrant Catholic and Jewish communities countered by creating their own social assistance organizations. $^{41}$

Over time, however, organizations with religious roots became more secular. Protestant congregations spun off separate secular civic organizations, and Catholic and Jewish social assistance institutions became religiouslysponsored, but government-friendly, agencies. Even before the New Deal, the highly centralized Catholic Church, with its large infrastructure of orphanages and hospitals, forged strong relationships with local politicians and gladly accepted local public funds. ${ }^{42}$ When the New Deal offered cities federal dollars, Northern and Midwestern cities used these resources to assist European immigrants, and in the process strengthened social service 
organizations with federally supported employees. ${ }^{43}$ Mainline Protestant, Catholic, and Jewish organizations also established national federations, positioning these organizations to grow when the federal spigot opened to fund private social service agencies in the 1960s. ${ }^{44}$ Over time, these religious federations became highly professionalized and gained "extensive experience implementing government contracts." 45

African Americans and Latinos could not count on equal treatment in Northern and Midwestern cities but they could expect their claims for public assistance to receive some attention. ${ }^{46}$ Black churches and missions offered support to those excluded from white-serving settlement houses as did the social-support institutions created by secular black reformers. ${ }^{47}$ Yet, it was not until the War on Poverty that independent black and Latino neighborhood organizations flourished with the support of federal dollars. ${ }^{48}$ Often church-related, these groups, such as New York's Abyssinian Baptist Church, were well positioned to command large-scale public funding in the era of devolution. ${ }^{49}$

In the South and the Mountain West, by contrast, limited European immigration, legalized racial hierarchy, and different religious traditions led to a very different configuration of social organization and government support for the poor. Although Progressive reformers created some social-welfare organizations in cities outside the North and Midwest, these regions lagged far behind in the number of secular benevolent organizations. ${ }^{50} \mathrm{In}$ the South, African Americans created their own religiously-linked social-welfare institutions, but political disenfranchisement meant little or no public funding. Segregated social institutions blocked the organizational cross-fertilization that was emerging in the North and Midwest in the 1960 s. $^{51}$ It likewise limited the development of community-based philanthropy. Comparing the South to the North and Midwest, David Hammack notes that "in religion and in other configurations of philanthropy and civil society the Gilded Age South was another country, or two other countries, white and black." ${ }^{\prime 52}$ Most of the philanthropic dollars that entered the South came from northern foundations, such as the Rockefeller Foundation and the Julius Rosenwald Fund, both of which provided vital support for black education. ${ }^{53}$ In the Mountain West and the Pacific West, Mexican immigrants faced deportation as the Great Depression deepened, leaving little institutional legacy on which to build organizations to assist the needy. ${ }^{54}$ Both regions remained influenced by Progressive-era reforms that included voting restrictions and elite-dominated politics well into the $1960 \mathrm{~s}^{55}$

Low levels of European immigration also gave the South and Mountain West a distinctive religious profile. In place of the Catholics, Jews, and mainline Protestants that dominated in the North and Midwest, evangelical
Protestants thrived in the South and the Mountain West. The rise of evangelical Protestantism coincided with the formation of a distinctive southern identity in the antebellum South. ${ }^{56}$ As table 2 shows, evangelical Protestants continue to dominate in the South and the Mountain West to this day. ${ }^{57}$ These religious differences had significant implications for the growth of an organizational infrastructure to assist the poor. With their emphasis on personal salvation, evangelical denominations historically shunned government funding, preferring to pursue their charitable mission through their congregations. ${ }^{58}$ Yet, as noted earlier, congregations are quite constrained in the types and amount of social services and housing they can deliver. Moreover, the organization of evangelical religions makes them especially poor vehicles for redistribution. Compared to mainline Protestants and Catholics, the much less centralized structure of evangelical churches makes it difficult for them to organize services beyond the congregation and share resources across communities. Charitable giving as a percentage of income is higher within evangelical denominations than mainline Protestants and Catholics. ${ }^{59}$ However, the preference for delivering services through congregations and reluctance to engage with government means that the high levels of personal generosity do not result in expansive services to the poor.

Federal efforts to help build organizational capacity in these metros have achieved mixed results. The War on Poverty, the clearest example of "forceful federalism," succeeded in creating new organizations to serve poor communities in the South and Mountain West. Poor minority communities, long ignored by mainstream social-service agencies, especially benefitted from the new organizations. ${ }^{60}$ Even so, resistance from local elites meant that War on Poverty programs spent less in the South than in other regions. ${ }^{61}$ These metros remained ill equipped to benefit from the flow of funds after 1967 when the federal government authorized nongovernmental organizations to receive federal funds. ${ }^{62}$

Seeking to promote more engagement of religious organizations in assisting the poor, presidents, starting with Bill Clinton, implemented "charitable choice," a set of incentives designed to draw more religious organizations into delivering social services in the aftermath of welfare reform. Yet there is little evidence that these measures have prompted evangelicals to overcome their reluctance to accept public funds by accepting the prohibition on proselytizing that comes with them. ${ }^{63}$ African American congregations mark a striking departure from this pattern. As in the North, African American churches in the South and Mountain West exhibit much greater willingness to accept government funds. ${ }^{64}$ Indeed, in 1998, Chaves found that African American congregations were the most willing of all congregations to apply for government funds. ${ }^{65}$ Likewise in a survey of Atlanta-area religious 
Table 2

Religious affiliations in the twenty-five largest metros in five regions of the U.S., 2005-2009

\begin{tabular}{|c|c|c|c|c|c|}
\hline CBSA & $\begin{array}{c}\% \\
\text { Catholic }\end{array}$ & $\begin{array}{l}\% \text { Mainline } \\
\text { Protestant }\end{array}$ & $\begin{array}{c}\% \text { Evangelical } \\
\text { Protestant }\end{array}$ & $\begin{array}{c}\% \text { Black } \\
\text { Protestant }\end{array}$ & $\begin{array}{c}\% \text { No } \\
\text { Affiliation }\end{array}$ \\
\hline Salt Lake City, UT & 9 & 1 & 3 & 0 & 27 \\
\hline Pittsburgh, PA & 33 & 14 & 7 & 1 & 42 \\
\hline Chicago-Naperville-Joliet, IL-IN-WI & 34 & 5 & 10 & 2 & 43 \\
\hline $\begin{array}{l}\text { Providence-New Bedford-Fall River, } \\
\text { RI-MA }\end{array}$ & 47 & 5 & 3 & 0 & 43 \\
\hline Boston-Cambridge-Quincy, MA-NH & 44 & 5 & 3 & 0 & 43 \\
\hline $\begin{array}{l}\text { New York-Northern New Jersey-Long } \\
\text { Island, NY-NJ-PA }\end{array}$ & 37 & 4 & 4 & 1 & 44 \\
\hline Dallas-Fort Worth-Arlington, TX & 13 & 7 & 28 & 2 & 45 \\
\hline Houston-Baytown-Sugar Land, TX & 17 & 7 & 25 & 1 & 45 \\
\hline $\begin{array}{l}\text { Philadelphia-Camden-Wilmington, PA- } \\
\text { NJ-DE-MD }\end{array}$ & 33 & 9 & 6 & 2 & 45 \\
\hline $\begin{array}{l}\text { Minneapolis-St. Paul-Bloomington, } \\
\text { MN-WI }\end{array}$ & 22 & 15 & 13 & 0 & 48 \\
\hline $\begin{array}{l}\text { Los Angeles-Long Beach-Santa Ana, } \\
\text { CA }\end{array}$ & 34 & 2 & 9 & 1 & 49 \\
\hline Atlanta-Sandy Springs-Marietta, GA & 7 & 10 & 26 & 3 & 50 \\
\hline St. Louis, MO-IL & 20 & 7 & 17 & 2 & 51 \\
\hline Cincinnati-Middletown, $\mathrm{OH}-\mathrm{KY}-\mathrm{IN}$ & 19 & 7 & 16 & 1 & 55 \\
\hline Detroit-Warren-Livonia, MI & 21 & 5 & 11 & 3 & 55 \\
\hline San Diego-Carlsbad-San Marcos, CA & 26 & 2 & 10 & 0 & 56 \\
\hline Riverside-San Bernardino-Ontario, CA & 25 & 1 & 11 & 1 & 58 \\
\hline Tucson, AZ & 21 & 4 & 10 & 0 & 60 \\
\hline $\begin{array}{l}\text { Miami-Fort Lauderdale-Miami Beach, } \\
\text { FL }\end{array}$ & 19 & 2 & 11 & 2 & 62 \\
\hline San Francisco-Oakland-Fremont, CA & 21 & 4 & 6 & 1 & 62 \\
\hline Phoenix-Mesa-Scottsdale, AZ & 13 & 3 & 13 & 0 & 62 \\
\hline Denver-Aurora, CO & 16 & 5 & 11 & 0 & 63 \\
\hline Las Vegas-Paradise, NV & 18 & 1 & 8 & 0 & 64 \\
\hline Seattle-Tacoma-Bellevue, WA & 12 & 5 & 12 & 0 & 64 \\
\hline Tampa-St. Petersburg-Clearwater, FL & 11 & 5 & 14 & 1 & 65 \\
\hline
\end{tabular}

Sources: Association of Religion Data Archives 2010; author's calculations.

leaders, Owens found that the racial composition of the congregation was the single most important factor in predicting willingness to apply for public funding: predominantly black churches were five times more likely to express support for receiving public funds. ${ }^{66}$ However, black congregations that can provide a broad array of services remain exceptions, especially in low-income neighborhoods. ${ }^{67}$

Even with the exception of black churches, the legacies of the past left a much smaller infrastructure for assisting the poor in the South and the Mountain West. In the decades after World War II, evangelical leaders opposed government funding of religious organizations to deliver social services. They believed - with some accuracy-that public funding disproportionately benefited Catholics and mainline Protestants. Although their opposition faded by the 1980s, and large evangelical institutions such as universities and hospitals gladly accepted public funds, the evangelical infrastructure for assisting the poor continued to lag behind. ${ }^{68}$
Combined with the later timing of urbanization, the weak nonprofit infrastructure in the South and Mountain West facilitated the move to for-profit outsourcing. Most of the metros of the South and Mountain West were, at most, small cities at the end of World War II. Some were barely dots on the map. Much of their growth-both in population and in low-income population-occurred after 1980. Yet it is precisely during this time that for-profit organizations began to compete in earnest with nonprofits for government contracts focused on low-income people.

The welfare reform law of 1996, which transformed welfare into block grants and gave states wide discretion, has been accompanied by increased outsourcing to private firms. As states embraced the idea that markets could solve social problems better than government, large corporations, such as Lockheed Martin, entered the field of social services. ${ }^{69}$ Outsourcing to for-profits could more easily be justified as the logical decision in a context where nonprofit capacity was weak; moreover, a weaker nonprofit sector could not put up a fight against outsourcing to for-profit organizations. 


\section{The Metropolitan Institutional Support Index}

How do these distinct organizational legacies affect the contemporary institutional configuration of support for low-income Americans in metropolitan America? To find out we use four indicators to assess the organizational infrastructure for assisting the poor in different metropolitan areas. They include nonprofit spending focused on low-income residents; spending by local philanthropy and federated giving organizations; the size of the workforce that delivers services to low-income residents; and the percentage of the private sector workforce employed by for-profits. Because our interest is in understanding regional differences, our data set includes the five largest metropolitan areas in the North, Midwest, Pacific West, Mountain West, and South. ${ }^{70}$ The metros are listed by region in table 1 .

To gauge the strength of the civic sector, our first indicator measures the level of spending by nonprofit organizations that serve low-income populations. It relies on 2010 data from the National Center for Charitable Statistics to examine fourteen categories of organizations that specifically target low-income residents. These categories include food aid, homeless shelters, affordable housing, and human services. ${ }^{71} \mathrm{We}$ did not include health because it is difficult to disentangle spending on lowincome residents in this category. We cleaned the data to eliminate nonprofits that do not serve the local community or that do not serve low-income residents. ${ }^{72}$ We norm the aggregate expenditure for all nonprofit organizations serving low-income residents with respect to the size of the population (dollars per person). ${ }^{73}$ We rely on the 2005-2009 American Community Survey for population estimates corresponding to our uniformly defined metropolitan areas over time. ${ }^{74}$

Our second indicator provides information about the strength of the local philanthropic sector, examining the spending of community-based philanthropy and federated giving programs, such as the United Way. Evidence for the impact of philanthropy on the density of the nonprofit sector is mixed. Studies that measure individual "philanthropic propensity" show no impact. Measured as "grants and donations given through private foundations or individual citizens," however, Lecy and Van Slyke show that philanthropy contributes positively to nonprofit density, albeit at a much lower level than government spending does. ${ }^{75}$ But philanthropic organizations also matter for civic capacity because they can serve as an organizational coordinating point for the nonprofit community. ${ }^{76}$ Community foundations and federated organizations such as the United Way play a special role in this regard since they have an explicit geographical mission. These organizations provide information, training, and connections that build a community of expertise around human services and affordable housing. As such they help nurture the supply of organizational founders and administrators whose presence contributes to a robust nonprofit sector. ${ }^{77}$ The combination of geographic reach and information resources makes these organizations especially well situated to identifying new needs and helping to start new organizations to address them. ${ }^{78}$ Recognizing their importance for civic capacity but their limited impact on spending, we combine these two measures into a single indicator relying on data from the NCCS data set.

Our third and fourth indicators assess the extent and character of the social-service sector, providing measures of the total size of the social-services workforce and distinguishing whether the services are delivered by employees in the public, nonprofit, or for-profit sector. The total size of the social assistance workforce captures the scope of this sector regardless of its public or private character. If some metropolitan areas compensate for small nonprofit sectors with large public or for-profit social-services sectors, we would see that reflected in this indicator. Using Quarterly Workforce Indicators, we aggregate public and private employment data in three social assistance categories. Within the social assistance classification, we selected three of four sub-categoriesfamily services; community food and housing, and emergency and other relief services; vocational and rehabilitation services. ${ }^{79}$ We excluded childcare services because it includes organizations serving all income groups.

The percentage of private-sector employees in the forprofit sector captures the prevalence of for-profit versus nonprofit service providers. Using the Economic Census, we aggregate employment in the social assistance sector. We selected the same social assistance categories as those used for the previous workforce indicator.

As a first strategy for identifying regional patterns, we construct a simple Metropolitan Institutional Support Index to rank our twenty-five metro areas on each of these measures. The index assigns a 1 if the metro is above the median in nonprofit spending and a 0 if equal to or below; 1 if the spending of community foundations and federated giving programs is above the median and a 0 if equal to or below; 1 if the metro is above the median in total social-service employment; and 1 if the metro is below the median in percent for-profit and 0 if it is equal to or above the median. The scores are then aggregated so that metros receive a final ranking between 4 and 0 . A score of 4 represents a strong civic sector, robust community philanthropy, a large social service and housing support sector, and relatively low for-profit outsourcing. A score of 0 represents the weakest social assistance sectors with low nonprofit capacity, weak philanthropy, and high levels of for-profit outsourcing.

As table 3 shows, the index displays a clear regional pattern corresponding to the two models of organizational infrastructure. Eight of the metros that received scores of 3 or 4 were in the North and the Midwest, with two 
Table 3

Metropolitan Institutional Support Index, 2010

\begin{tabular}{|c|c|c|c|c|c|}
\hline CBSA & $\begin{array}{c}\text { Nonprofit Social Services } \\
\text { Spending (\$ per person)- } \\
\text { ABOVE MEDIAN }\end{array}$ & $\begin{array}{c}\text { Community } \\
\text { Foundation } \\
\text { and } \\
\text { Federated } \\
\text { Giving } \\
\text { Program } \\
\text { Spending } \\
\text { (\$ per } \\
\text { person)- } \\
\text { ABOVE } \\
\text { MEDIAN }\end{array}$ & $\begin{array}{c}\text { Social Service Sector } \\
\text { Employment per 100,000- } \\
\text { ABOVE MEDIAN }\end{array}$ & $\begin{array}{l}\text { Percent of } \\
\text { Private } \\
\text { Employees } \\
\text { in For-Profit } \\
\text { - BELOW } \\
\text { MEDIAN }\end{array}$ & $\begin{array}{l}\text { Metro } \\
\text { Index }\end{array}$ \\
\hline $\begin{array}{l}\text { San Francisco-Oakland- } \\
\text { Fremont, CA }\end{array}$ & 1 & 1 & 1 & 1 & 4 \\
\hline $\begin{array}{l}\text { New York-Northern New } \\
\text { Jersey-Long Island, } \\
\text { NY-NJ-PA }\end{array}$ & 1 & 1 & 1 & 1 & 4 \\
\hline Pittsburgh, PA & 1 & 1 & 1 & 1 & 4 \\
\hline $\begin{array}{l}\text { Cincinnati-Middletown, } \\
\mathrm{OH}-\mathrm{KY}-\mathrm{IN}\end{array}$ & 1 & 1 & 1 & 1 & 4 \\
\hline $\begin{array}{l}\text { Boston-Cambridge- } \\
\text { Quincy, MA-NH }\end{array}$ & 1 & 0 & 1 & 1 & 3 \\
\hline $\begin{array}{l}\text { Minneapolis-St. Paul- } \\
\text { Bloomington, MN-WI }\end{array}$ & 1 & 1 & 1 & 0 & 3 \\
\hline Tucson, AZ & 1 & 0 & 1 & 1 & 3 \\
\hline $\begin{array}{c}\text { Seattle-Tacoma- } \\
\text { Bellevue, WA }\end{array}$ & 1 & 1 & 1 & 0 & 3 \\
\hline $\begin{array}{l}\text { Providence-New } \\
\text { Bedford-Fall River, } \\
\text { RI-MA }\end{array}$ & 1 & 0 & 1 & 1 & 3 \\
\hline $\begin{array}{l}\text { Philadelphia-Camden- } \\
\text { Wilmington, PA-NJ- } \\
\text { DE-MD }\end{array}$ & 1 & 0 & 1 & 1 & 3 \\
\hline $\begin{array}{l}\text { Chicago-Naperville- } \\
\text { Joliet, IL-IN-WI }\end{array}$ & 1 & 1 & 0 & 1 & 3 \\
\hline Denver-Aurora, CO & 0 & 1 & 1 & 0 & 2 \\
\hline $\begin{array}{l}\text { Detroit-Warren-Livonia, } \\
\text { MI }\end{array}$ & 0 & 1 & 0 & 1 & 2 \\
\hline St. Louis, MO-IL & 0 & 1 & 1 & 0 & 2 \\
\hline $\begin{array}{l}\text { San Diego-Carlsbad- } \\
\text { San Marcos, CA }\end{array}$ & 1 & 0 & 0 & 0 & 1 \\
\hline Salt Lake City, UT & 0 & 0 & 0 & 1 & 1 \\
\hline $\begin{array}{l}\text { Tampa-St. Petersburg- } \\
\text { Clearwater, FL }\end{array}$ & 0 & 0 & 0 & 1 & 1 \\
\hline $\begin{array}{l}\text { Dallas-Fort Worth- } \\
\text { Arlington, TX }\end{array}$ & 0 & 1 & 0 & 0 & 1 \\
\hline $\begin{array}{l}\text { Miami-Fort Lauderdale- } \\
\text { Miami Beach, FL }\end{array}$ & 0 & 0 & 0 & 1 & 1 \\
\hline $\begin{array}{l}\text { Atlanta-Sandy Springs- } \\
\text { Marietta, GA }\end{array}$ & 0 & 1 & 0 & 0 & 1 \\
\hline $\begin{array}{l}\text { Los Angeles-Long } \\
\text { Beach-Santa Ana, CA }\end{array}$ & 0 & 0 & 0 & 0 & 0 \\
\hline $\begin{array}{l}\text { Phoenix-Mesa- } \\
\text { Scottsdale, AZ }\end{array}$ & 0 & 0 & 0 & 0 & 0 \\
\hline $\begin{array}{l}\text { Houston-Baytown- } \\
\text { Sugar Land, TX }\end{array}$ & 0 & 0 & 0 & 0 & 0 \\
\hline $\begin{array}{l}\text { Riverside-San } \\
\text { Bernardino-Ontario, } \\
\text { CA }\end{array}$ & 0 & 0 & 0 & 0 & 0 \\
\hline $\begin{array}{l}\text { Las Vegas-Paradise, } \\
\text { NV }\end{array}$ & 0 & 0 & 0 & 0 & 0 \\
\hline
\end{tabular}

Sources: National Center for Charitable Statistics 2010, U.S. Census Bureau 2009a, 2012b, 2014; author's calculations.

Note: Shading distinguishes metropolitan areas with a high, medium, and low score on the Index: Light grey=3 or 4; Medium grey=2; Dark grey $=0$ or 1 . 
Table 4

Metropolitan Indicators, 2010

\begin{tabular}{|c|c|c|c|c|}
\hline CBSA & $\begin{array}{l}\text { Nonprofit Social } \\
\text { Services Spending } \\
\text { (\$ per person) }\end{array}$ & $\begin{array}{c}\text { Community } \\
\text { Foundation and } \\
\text { Federated Giving } \\
\text { Program Spending (\$ } \\
\text { per person) }\end{array}$ & $\begin{array}{l}\text { Social Service Sector } \\
\text { Employment per } \\
100,000 \text { persons }\end{array}$ & $\begin{array}{l}\text { Percent of } \\
\text { Private } \\
\text { Employees in } \\
\text { For-Profit }\end{array}$ \\
\hline $\begin{array}{l}\text { San Francisco- } \\
\text { Oakland-Fremont, } \\
\text { CA }\end{array}$ & 333 & 104 & 582 & 27 \\
\hline $\begin{array}{l}\text { New York-Northern } \\
\text { New Jersey-Long } \\
\text { Island, NY-NJ-PA }\end{array}$ & 259 & 64 & 1,053 & 15 \\
\hline Pittsburgh, PA & 216 & 52 & 931 & 22 \\
\hline $\begin{array}{l}\text { Cincinnati- } \\
\text { Middletown, OH- } \\
\text { KY-IN }\end{array}$ & 166 & 88 & 642 & 28 \\
\hline $\begin{array}{l}\text { Boston-Cambridge- } \\
\text { Quincy, MA-NH }\end{array}$ & 294 & 44 & 730 & 15 \\
\hline $\begin{array}{l}\text { Minneapolis-St. Paul- } \\
\text { Bloomington, MN- } \\
\text { WI }\end{array}$ & 285 & 89 & 1,353 & 31 \\
\hline Tucson, AZ & 246 & 44 & 688 & 27 \\
\hline $\begin{array}{c}\text { Seattle-Tacoma- } \\
\text { Bellevue, WA }\end{array}$ & 238 & 67 & 849 & 33 \\
\hline $\begin{array}{l}\text { Providence-New } \\
\text { Bedford-Fall River, } \\
\text { RI-MA }\end{array}$ & 219 & 47 & 766 & 13 \\
\hline $\begin{array}{l}\text { Philadelphia-Camden- } \\
\text { Wilmington, PA-NJ- } \\
\text { DE-MD }\end{array}$ & 214 & 38 & 900 & 20 \\
\hline $\begin{array}{l}\text { Chicago-Naperville- } \\
\text { Joliet, IL-IN-WI }\end{array}$ & 182 & 83 & 568 & 24 \\
\hline Denver-Aurora, CO & 151 & 72 & 670 & 51 \\
\hline $\begin{array}{l}\text { Detroit-Warren- } \\
\text { Livonia, MI }\end{array}$ & 130 & 54 & 483 & 23 \\
\hline St. Louis, MO-IL & 129 & 48 & 621 & 31 \\
\hline $\begin{array}{l}\text { San Diego-Carlsbad- } \\
\text { San Marcos, CA }\end{array}$ & 164 & 37 & 459 & 34 \\
\hline Salt Lake City, UT & 137 & 15 & 569 & 28 \\
\hline $\begin{array}{l}\text { Tampa-St. } \\
\text { Petersburg- } \\
\text { Clearwater, FL }\end{array}$ & 131 & 20 & 335 & 21 \\
\hline $\begin{array}{l}\text { Dallas-Fort Worth- } \\
\text { Arlington, TX }\end{array}$ & 121 & 64 & 293 & 32 \\
\hline $\begin{array}{l}\text { Miami-Fort } \\
\text { Lauderdale-Miami } \\
\text { Beach, FL }\end{array}$ & 111 & 41 & 342 & 21 \\
\hline $\begin{array}{l}\text { Atlanta-Sandy } \\
\text { Springs-Marietta, } \\
\text { GA }\end{array}$ & 76 & 56 & 375 & 44 \\
\hline $\begin{array}{l}\text { Los Angeles-Long } \\
\text { Beach-Santa Ana, } \\
\text { CA }\end{array}$ & 151 & 36 & 457 & 35 \\
\hline $\begin{array}{l}\text { Phoenix-Mesa- } \\
\text { Scottsdale, AZ }\end{array}$ & 112 & 32 & 430 & 54 \\
\hline $\begin{array}{l}\text { Houston-Baytown- } \\
\text { Sugar Land, TX }\end{array}$ & 93 & 34 & 324 & 52 \\
\hline
\end{tabular}

(continued) 
Table 4

Metropolitan Indicators, 2010 (continued)

\begin{tabular}{lcccc}
\hline & $\begin{array}{c}\text { Community } \\
\text { Services Spending } \\
\text { (\$ per person) }\end{array}$ & $\begin{array}{c}\text { Foundation and } \\
\text { Federated Giving } \\
\text { Program Spending (\$ } \\
\text { per person) }\end{array}$ & $\begin{array}{c}\text { Social Service Sector } \\
\text { Employment per } \\
\text { 100,000 persons }\end{array}$ & $\begin{array}{c}\text { Percent of } \\
\text { Private } \\
\text { Employees in } \\
\text { For-Profit }\end{array}$ \\
\hline $\begin{array}{l}\text { Riverside-San } \\
\text { Bernardino-Ontario, } \\
\text { CA }\end{array}$ & 70 & 7 & 235 & 44 \\
$\begin{array}{l}\text { Las Vegas-Paradise, } \\
\text { NV }\end{array}$ & 66 & 21 & 475 & 51 \\
\hline
\end{tabular}

Sources: National Center for Charitable Statistics 2010. U.S. Census Bureau 2009a, 2012b, 2014; author's calculations.

Note: Shading distinguishes metropolitan areas with a high, medium, and low score on the Index: Light grey=3 or 4; Medium grey=2; Dark grey $=0$ or 1 .

(San Francisco and Seattle) in the Pacific West and one (Tucson) in the Mountain West. Eight of the eleven metros that received scores of 0 or 1 were in the South and Mountain West, with three in the Pacific West (San Diego, Los Angeles, and Riverside). Table 4 presents the raw data and table 5 the $\mathrm{Z}$ scores for the indicators. With the exception of Tucson, these measures confirm the general regional pattern of a much stronger civic sector as defined by the level of nonprofit spending and philanthropic giving in the North and Midwestern metros and a much weaker civic sector in the South and Mountain West metros. Pacific West metros exhibited a mixed pattern with San Francisco and Seattle ranking in the top group. The employment indicators for outsourcing to for-profits versus nonprofits show a similar regional pattern, with such outsourcing far more prevalent in the South and Mountain West. Three metros, Denver, Detroit, and St. Louis, receive the middle score of 2.

To further test these regional patterns we constructed a second version of our index incorporating a measure of independent foundation spending into the philanthropy indicator. This data was drawn from the Foundation Center's research data set of the 1,000 largest independent foundations. ${ }^{80}$ The new philanthropy indicator combined standardized variables for community foundation, federated giving program, and independent foundation spending in order to equally weight spending by any of the three types of foundations because of the limited number of foundations in the Foundation Center data. We do not report the alternative philanthropy indicator here because it is impossible to know whether the limitations of the Foundation Center data introduce bias. The alternative measure resulted in only minor changes to the indicators for two metropolitan areas-St. Louis's philanthropy indicator flipped from 1 to 0 , and Boston's philanthropy indicator flipped from 0 to 1 .

In sum, the regional patterns that first took root over a hundred years ago remain evident in contemporary configurations of institutional support for low-income people. Yet the metros that depart from their regional pattern and the metros in the middle category invite questions about the broader trajectory of these models in the future.

\section{Trajectories of Change}

What will drive the future trajectory of the two models? Will the civic-public model and the religious-private model steadily come to resemble one another or will they follow distinct paths? One possibility is that federal social-policy retrenchment will cause the two models to converge with the civic-public model eroding as public funding shrinks. Another possibility is that the two models will move in different directions as the organizations in the civic-public model use their power to enhance the resources going to nonprofits and restrict the role of for-profit firms in social service delivery. By contrast, regions with the religious-private model may delegate more resources to for-profit firms even if they increase spending. Finally, as regions confront economic and demographic change, the boundaries between the two models may begin to blur.

When we examine change in nonprofit spending between 1990 and 2010, metros in all parts of the country display growth but with a few exceptions, the highest nonprofit spenders in the South and Mountain West remain below those in the North and Midwest, evidence of the enduring significance of the civic-public and religious-private models for the nonprofit infrastructure for serving the poor.

Yet, the experience of Detroit suggests that the civicpublic model can become vulnerable. Like St. Louis, it sits in the middle of our index. Unlike St. Louis, however, Detroit had a much higher level of nonprofit spending in 1990, and over the next twenty years nonetheless lagged behind the growth rates of other metros in the North and Midwest. ${ }^{81}$ A weak local 
Table 5

Metropolitan Indicator Z-scores, 2010

\begin{tabular}{|c|c|c|c|c|}
\hline CBSA & $\begin{array}{l}\text { Nonprofit Social } \\
\text { Services Spending } \\
\text { (\$ per person)-Z- } \\
\text { SCORE }\end{array}$ & $\begin{array}{c}\text { Community } \\
\text { Foundation and } \\
\text { Federated Giving } \\
\text { Program Spending } \\
\text { (\$ per person)- Z- } \\
\text { SCORE }\end{array}$ & $\begin{array}{l}\text { Social Service } \\
\text { Sector Employment } \\
\text { per 100,000-Z- } \\
\text { SCORE }\end{array}$ & $\begin{array}{l}\text { Percent of Private } \\
\text { Employees in For- } \\
\text { Profit-Z-SCORE }\end{array}$ \\
\hline $\begin{array}{l}\text { San Francisco- } \\
\text { Oakland-Fremont, } \\
\text { CA }\end{array}$ & 2.18 & 2.22 & -0.09 & -0.36 \\
\hline $\begin{array}{l}\text { New York-Northern } \\
\text { New Jersey-Long } \\
\text { Island, NY-NJ-PA }\end{array}$ & 1.17 & 0.55 & 1.69 & -1.31 \\
\hline Pittsburgh, PA & 0.59 & 0.08 & 1.23 & -0.70 \\
\hline $\begin{array}{l}\text { Cincinnati- } \\
\text { Middletown, OH- } \\
\text { KY-IN }\end{array}$ & -0.07 & 1.54 & 0.14 & -0.23 \\
\hline $\begin{array}{c}\text { Boston-Cambridge- } \\
\text { Quincy, MA-NH }\end{array}$ & 1.65 & -0.27 & 0.47 & -1.31 \\
\hline $\begin{array}{l}\text { Minneapolis-St. } \\
\text { Paul-Bloomington, } \\
\text { MN-WI }\end{array}$ & 1.53 & 1.58 & 2.82 & -0.01 \\
\hline Tucson, AZ & 1.01 & -0.26 & 0.31 & -0.33 \\
\hline $\begin{array}{c}\text { Seattle-Tacoma- } \\
\text { Bellevue, WA }\end{array}$ & 0.89 & 0.67 & 0.92 & 0.16 \\
\hline $\begin{array}{l}\text { Providence-New } \\
\text { Bedford-Fall River, } \\
\text { RI-MA }\end{array}$ & 0.64 & -0.12 & 0.61 & -1.51 \\
\hline $\begin{array}{l}\text { Philadelphia- } \\
\text { Camden- } \\
\text { Wilmington, PA- } \\
\text { NJ-DE-MD }\end{array}$ & 0.58 & -0.51 & 1.11 & -0.92 \\
\hline $\begin{array}{l}\text { Chicago-Naperville- } \\
\text { Joliet, IL-IN-WI }\end{array}$ & 0.14 & 1.33 & -0.14 & -0.56 \\
\hline Denver-Aurora, CO & -0.28 & 0.91 & 0.24 & 1.62 \\
\hline $\begin{array}{l}\text { Detroit-Warren- } \\
\text { Livonia, MI }\end{array}$ & -0.56 & 0.15 & -0.46 & -0.66 \\
\hline St. Louis, MO-IL & -0.58 & -0.11 & 0.06 & 0.01 \\
\hline $\begin{array}{l}\text { San Diego-Carlsbad- } \\
\text { San Marcos, CA }\end{array}$ & -0.11 & -0.53 & -0.55 & 0.27 \\
\hline Salt Lake City, UT & -0.47 & -1.46 & -0.14 & -0.22 \\
\hline $\begin{array}{l}\text { Tampa-St. } \\
\text { Petersburg- } \\
\text { Clearwater, FL }\end{array}$ & -0.55 & -1.26 & -1.02 & -0.86 \\
\hline $\begin{array}{l}\text { Dallas-Fort Worth- } \\
\text { Arlington, TX }\end{array}$ & -0.68 & 0.56 & -1.18 & 0.07 \\
\hline $\begin{array}{l}\text { Miami-Fort } \\
\text { Lauderdale-Miami } \\
\text { Beach, FL }\end{array}$ & -0.82 & -0.40 & -0.99 & -0.86 \\
\hline $\begin{array}{l}\text { Atlanta-Sandy } \\
\text { Springs-Marietta, } \\
\text { GA }\end{array}$ & -1.29 & 0.25 & -0.87 & 1.08 \\
\hline $\begin{array}{l}\text { Los Angeles-Long } \\
\text { Beach-Santa Ana, } \\
\text { CA }\end{array}$ & -0.28 & -0.60 & -0.56 & 0.32 \\
\hline $\begin{array}{l}\text { Phoenix-Mesa- } \\
\text { Scottsdale, AZ }\end{array}$ & -0.81 & -0.74 & -0.66 & 1.85 \\
\hline $\begin{array}{l}\text { Houston-Baytown- } \\
\text { Sugar Land, TX }\end{array}$ & -1.06 & -0.65 & -1.06 & 1.74 \\
\hline
\end{tabular}

(continued) 
Table 5

Metropolitan Indicator Z-scores, 2010 (continued)

\begin{tabular}{|c|c|c|c|c|}
\hline CBSA & $\begin{array}{l}\text { Nonprofit Social } \\
\text { Services Spending } \\
\text { (\$ per person)-Z- } \\
\text { SCORE }\end{array}$ & $\begin{array}{l}\text { Community } \\
\text { Foundation and } \\
\text { Federated Giving } \\
\text { Program Spending } \\
\text { (\$ per person)- Z- } \\
\text { SCORE }\end{array}$ & $\begin{array}{l}\text { Social Service } \\
\text { Sector Employment } \\
\text { per } 100,000-Z- \\
\text { SCORE }\end{array}$ & $\begin{array}{l}\text { Percent of Private } \\
\text { Employees in For- } \\
\text { Profit-Z-SCORE }\end{array}$ \\
\hline $\begin{array}{l}\text { Riverside-San } \\
\text { Bernardino- } \\
\text { Ontario, CA }\end{array}$ & -1.37 & -1.76 & -1.40 & 1.07 \\
\hline $\begin{array}{l}\text { Las Vegas-Paradise, } \\
\text { NV }\end{array}$ & -1.43 & -1.19 & -0.49 & 1.66 \\
\hline
\end{tabular}

economy is part of the explanation. Detroit's CBSA, experienced an 8.5 percent drop in median household income between 1990 and 2010, the most severe decline of all our metros. ${ }^{82}$ Indeed, when it comes to nonprofit spending, economic growth matters: our 25 metros show a .46 correlation between the growth of median household income and a rise in nonprofit spending over these twenty years.

In addition to declining income, Detroit points to the ongoing role of race in influencing the infrastructure of support for the poor. Depleted by white exodus and decades of decline, Detroit's nonprofits have strained to support low-income residents, while the city itself fell into bankruptcy. Detroit also highlights the importance of the principal city for the vitality of the nonprofit infrastructure in the region as a whole. When largely black central cities have been left to struggle with rising rates of poverty and declining tax bases, the nonprofit sector of the entire region suffers. Indeed, among our North and Midwest metros, the cities of Detroit and St. Louis have the two largest black populations at 82.7 percent and 49.2 percent respectively. ${ }^{83}$

State spending also shapes the trajectory of the models. Data from the Census of Governments places Michigan near the bottom of all our metros in state spending growth on public welfare and housing and community development from 1992 to $2012 .{ }^{84}$ But local factors can create large differences even within states, as the case of California suggests. The three metros in California-San Francisco, Los Angeles, and Riverside-reveal the difficulty of building a strong nonprofit sector in metros whose history diverges from that of cities in the North and Midwest. San Francisco, whose nineteenth- and early twentieth-century history resembles that of the North and Midwest, sits at the top of our index, Los Angeles in the lower category, and Riverside near the bottom. As important as state spending is, these California metros indicate the importance of specifically local factors in building a robust nonprofit sector to serve low-income residents.

European immigration was central to the historical development of the civic-public model, but it is not clear how contemporary immigration affects trajectories of nonprofit development. Demand-side arguments about nonprofit density posit that a more diverse population will produce a bigger nonprofit sector by boosting demand for culturally-specific programs, best provided for by nongovernmental organizations. When we examine our 25 metros, however, we see only a weak negative correlation of .04 between nonprofit spending and foreign-born population in 2010. But a comparison of our two regional models reveals something different. The correlation between foreign-born and nonprofit spending is positive at .2 for the metros in the North and Mideast and a negative .4 correlation for the South and Mountain West. One interpretation is that areas with strong nonprofits increase their capacity as immigration increases, while areas with weak nonprofits cannot respond to a rise in immigration in a comparable way. The divergence between the regions provides support for a supply model of nonprofit growth advanced by Frumkin. ${ }^{85}$ The preexisting supply of organizations and personnel in the North and Midwest makes it easier to expand nonprofit capacity to respond to immigrants and can ultimately lead to a virtuous cycle of immigrant incorporation. ${ }^{86}$ By contrast, in the South and Mountain West, the weakness of these local resources means that the rise in immigration does not engender a response of comparable scale in the nonprofit sector.

The impact of the timing of urbanization is evident in divergent patterns of employment in the for-profit social services. To be sure, the growth of for-profit provision affected all areas of the country. Between 2002 and 2012, the for-profit sector share of private social services employment grew by roughly similar percentages in all regions of the country. However, the balance between 
for-profit providers and nonprofit providers varied sharply across the regions, reflecting their very different starting points. In the Northern states, the for-profit sector grew from 9.7 percent of all private employment in the social services in 2002 to 18.5 percent in 2012. In the South, for-profit employment grew from 14 percent to 37 percent in the same time period. By 2012, for-profits accounted for 41 percent of the private employment in social assistance in the Mountain West metros. ${ }^{87}$

These trends suggest that if social spending in the South and the Mountain West were to "catch up" to the other areas of the country, the additional spending would do little to expand the nonprofit sector. In the absence of a strong nonprofit sector, for-profit providers face few barriers to entry. And for public officials, for-profits may present the simplest and most efficient choice for providing services as their populations and needs grow. But many of the metros with large for-profit sectors, such as Riverside, Las Vegas, and Phoenix also have very small public sectors. The public-sector social-services workforce in these metros is relatively small, with 2,9 , and 17 employees per 100, 000 persons, respectively compared to an average of 44 employees per 100,000 persons in our metros. ${ }^{88}$ With weak public capacities, these metros are poorly equipped to conduct the monitoring of for-profits needed to guard against rent seeking and cherry picking clients.

Philanthropic assistance offers a possible source of external support to spark change in nonprofit strength. A handful of large national philanthropic organizations have played a major role in building the nationwide nonprofit infrastructure for affordable housing and have simultaneously bolstered a wide range of social services. ${ }^{89}$ Foundation funding is widely valued because it supports innovation and organizational networking that public dollars rarely support. Yet a recent review of 169,000 community- and economic-development grants by the largest foundations between 2008 and 2013 found that "the density of nonprofit organizations and the presence of large local foundations" were the best predictors of grant receipt. ${ }^{90}$ As this study and other similar findings indicate, foundations contribute to the virtuous cycle in the North and Midwest where nonprofits are historically strong but they find fewer toeholds for involvement in places with historically weak nonprofit sectors. ${ }^{91}$

Over one hundred years ago, demographic and religious forces created the unique alchemy that lay behind the civic-public model of assistance in the North and Midwest. The very different history of the South and the Mountain West fostered a private-religious organizational configuration, which provides weaker support to lowincome residents. These regional differences have largely endured and taken on a new dimension with the growth of for-profit services. Patterns of change over the past two decades suggest that the institutional arrangements that support the two models will be difficult to alter. Within this overall pattern, higher income metros enjoy an advantage when it comes to creating new nonprofit capacities. America's delegated state puts poor residents in declining Midwestern metros, especially those with large black populations, at risk of reduced services. Simultaneously, though for different reasons, it leaves less well-off metros in the South and Mountain West with a frail set of institutions to serve the poor.

By clarifying the enduring effects of two distinct developmental patterns, the historical-institutional approach to subnational variation helps to reconcile the disparate threads in contemporary studies of nonstate organizations in American social policy. These studies tend to fall into one of two streams: efforts to document bottom-up organizational creativity or the impact of topdown policies of retrenchment. In emphasizing organizational innovation, the former research stream views the emergence of the third sector in largely positive terms. Research has documented the growing capacity of Community Development Corporations (CDCs) since the 1970s and the system of philanthropically supported finance that has made them the main vehicle for building affordable housing. ${ }^{92}$ Likewise, studies have praised the growth of large human service organizations capable of delivering a diverse array of social programs. ${ }^{93}$ The second research stream, in focusing on retrenchment, tells a very different story. In place of ever-growing organizational capacity, this work highlight the holes in social provision, the subterranean politics that makes it difficult to monitor private rent seeking, and cuts in public funding that weaken nonprofits or lead them to act more like forprofits. $^{94}$

Analyses that celebrate organizational creation tend to treat places where these innovations have not thrived as exceptions that will eventually learn to innovate. By contrast, studies that emphasize retrenchment highlight the power of federal and state policy to undermine local arrangements. We argue, instead, that there may be a distinct institutional logic to the "underperforming" places that puts them on fundamentally different trajectories. Similarly, economically strong regions with longestablished nonprofit sectors may have more ability to withstand federal retrenchment policies.

\section{Conclusion}

Arguments about retrenchment and the delegated state put the focus on federal action, while studies of organizational innovation track developments in civil society. In contrast to these perspectives, we find that the impact of federal policies depends critically on their interaction with local social organization. Distinct histories of immigration, race, and religion and the timing of urbanization have created very different organizational configurations for serving the poor in different regions of the United 
States. The expansion of the federal social role in the 1930s and the 1960s did not erase these differences: even at their most directive, federal initiatives built on local social organization. Without external support for institution-building, the infrastructure for assisting the poor will remain weak in the South and Mountain West, especially in less affluent metros, where it is needed most. In Northern and Midwestern cities, well-established clusters of organizations have endured ups and downs of federal support. Yet even the most robust nonprofit sectors in North and Midwest metros would falter without the federal dollars that have supported their growth since the 1960s. As the experience of poorer Midwestern metros underscores, the infrastructure in these regions can become vulnerable. These failings matter because the delegated state, with its implicitly bottom-up perspective on organizational creation, has few mechanisms for remedying institutional failings.

In his blueprint for reorganizing federal systems of social support, "A Better Way," Speaker Paul Ryan claimed that federal overreach was damaging nongovernmental institutions that serve the needy "because it substitutes federal power in their place." $"$ In fact, the contrast that we document shows that infrastructure to serve the poor achieved significant growth only when the federal government supplied resources to local institutions or when it directly helped build local organizations. Although the idea that civil-society organizations will flourish once freed from government remains a staple of conservative rhetoric, the regional disparities that have crystallized over the last century demonstrate exactly the opposite.

\section{Notes}

1 Snell and DeBonis 2016.

2 Salamon 1987; Smith and Lipsky 1992.

3 Clemens 2010; Morris 2004.

4 Allard 2008.

5 Morgan and Campbell 2011; Soss, Fording, and Schram 2011.

6 Hasenfeld and Garrow 2012.

7 Frumkin 2009; Lecy and Van Slyke 2013.

8 As we show later in the article, the Pacific West exhibits a mixed pattern due to the different timing of urbanization and variation in the presence of European immigrants in this region.

9 Cammett and MacLean 2014; Mettler 1998; Weir 2005.

10 Howard 2007, 178-191.

11 Soss, Fording, and Schram 2011; Hero and Preuhs 2006; Howard 2007.

12 Pettijohn et al. 2013, 7.

13 Soss, Fording, and Schram 2011.

14 Bruch, Meyers, and Gornick 2016.

15 Hajnal and Trounstine 2010, 1144.

16 Esping-Andersen 1990.
17 For a discussion of configurative analysis see Katznelson 1997; on historical institutionalist approaches considering how such configurations change and persist over time see Mahoney and Thelen 2010.

18 Morgan and Orloff 2017.

19 Clemens 2017; this historical perspective resonates with Salamon and Anheier's 1998 "social origins approach" to explaining cross-national differences in the development of social services: similar to EspingAndersen, they portray United States as a unified case of liberal development.

20 Esping-Andersen 1990; Salamon and Anheier 1998. For an analysis that points to the importance of centerperiphery relations for analyzing social services, see Alber 1995.

21 Fox 2012.

22 King 2017.

23 Soss, Fording, and Schram 2011, 112-140.

24 Allard 2008; Edin and Shaefer 2015.

25 Reckhow 2013.

26 Lowry and Potoski 2004.

27 Yerena 2015; Paarlberg and Varda 2009.

28 Smith and Lipsky 1992; Smith and Grønbjerg 2006; Salamon 1987.

29 Smith 2012.

30 Mosley 2010; Berry and Aarons 2003; Smith 2012.

31 Graddy and Morgan 2006; Reckhow and Weir 2012.

32 Chaves and Tsitsos 2001; Chaves 2001.

33 Chaves and Eagle, 2015, 53.

34 Smith 2012, 211.

35 Ibid.

36 Morgan and Campbell 2011; Soss, Fording, and Schram 2011, 176-206.

37 Fox 2012.

38 Kahl 2005; Van Kersbergen and Manow 2009; Morgan 2006, Alber 1995.

39 Kahl 2005; Scheve and Stasavage 2006; GryzmalaBusse 2012.

40 Kahl 2005.

41 Katz 1987; Hall 2006; Brown and McKeown 1997.

42 Oates 2003; Brown and McKeown 1997.

43 Fisher and Fabricant 2002, 11-12; Lasch-Quinn 1993, 65.

44 McCarthy and Castelli 1999; Brown and McKeown 1997; Adloff 2006.

45 Bielefeld and Cleveland 2013, 482.

46 Fox 2012, 199-201; on St. Louis, for example, see Dowden-White 2011.

47 Lasch-Quinn 1993, 47-74; Fox 2012, 117.

48 Orleck and Hazirjian 2011.

49 Owens 2008; Hyra 2008, 124-125.

50 Burke 2001, 192.

51 Lasch-Quinn 1993; Ferguson 2002.

52 Hammack 2017, 219. 
53 Hammack 2017; on the Rosenwald schools see Johnson 2010, 129-132.

54 Fox 2012, 81 provides evidence that the Catholic Church was less responsive to Mexican immigrants in Los Angeles.

55 Shefter 1983; Bridges 1999.

56 Wilson 2005, 12.

57 Grammich et al. 2012.

58 Chaves, Stephens, and Galaskiewicz 2004, 302; Wilson 2005.

59 Hoge 1995, 54.

60 Orleck and Hazirjian 2011.

61 Bailey and Duquette 2014.

62 Morris 2004.

63 Chaves and Wineburg 2010; Ebaugh, Chafetz, and Pipes 2006.

64 Chaves and Higgins 1992.

65 Chaves 2001.

66 Owens 2006, 57.

67 Owens and Smith 2005.

68 Schäfer 2012.

69 Soss, Fording, and Schram 2011, 176-206.

70 The U.S. Census defines four major regions. We pull out the Pacific West as a separate category because some of its metros are more similar historically to the North and Midwest, notably San Francisco and, to a lesser extent, Seattle. We define metropolitan areas as Core Based Statistical Areas (CBSAs) under the revised December 2003 definitions released by the Office of Management and Budget. For the definitions refer to http://www.census.gov/population/metro/files/lists/ 2003/0312mfips.txt.

71 Our National Taxonomy of Exempt Entities Core Codes (NTEE-CC) selections draw from Allard and Roth 2010, 35, but differ in that they exclude community health services, such as substance abuse and mental health treatment, and include affordable housing development organizations. We use the following NTEE-CC codes:

$\begin{array}{ll}\text { J20, J21, J22 } & \text { Employment Preparation and Procurement } \\ \text { K30, K31, K25 } & \text { Food Programs } \\ \text { L41 } & \text { Temporary Housing } \\ \text { L20 } & \text { Housing Development, Construction, and Management } \\ \text { L21 } & \text { Low-Income and Subsidized Rental Housing } \\ \text { L25, L30, L80, L82 } & \text { Housing Rehabilitation, Housing Search Assistance, Housing } \\ \text { Support, Housing Expense Reduction } & \text { Human Services } \\ \text { P30, P22, P24, P26, P28, P29 } & \text { Children and Youth Services } \\ \text { P40, P42, P43, P45 } & \text { Family Services } \\ \text { P60 } & \text { Emergency Assistance } \\ \text { P84 } & \text { Ethnic and Immigrant Center } \\ \text { P85 } & \text { Homeless Centers }\end{array}$

72 We implemented a data cleaning strategy designed to eliminate organizations that were either not serving low-income people or were national or international in focus, rather than local. We did this by checking the organization's website for indication of mission and service area. Organizations that did not meet our criteria were dropped from the data. In cases where no information was available online, the organization was kept. Data cleaning was carried out for organizations that comprised $80 \%$ of total spending in each of fourteen organizational categories for each metro in a given year. When organizations were eliminated, we checked additional organizations to make the proportion of organizations checked equivalent to $80 \%$ of spending. This approach to culling the data for cleaning allowed us to reduce the number of organizations that were checked, while insuring that the large organizations most likely to impact our analyses were evaluated.

73 We conducted these analyses norming for the numbers of people below the poverty line as well. Because the results were similar, we only report the data normed for total population.

74 U.S. Census Bureau 2009a, 2009 b.

75 Lecy and Van Slyke 2013.

76 Graddy and Morgan 2006.

77 Frumkin 2009.

78 Reckhow and Weir 2012.

79 Our categories came from North American Industry Classification System (NAIC), used in the Economic Census. We relied on 6241, 6242, 6243. The social assistance category may include some outpatient social services, but it excludes hospitals, nursing homes, and ambulatory services, which have their own classification in the health-and social-services sector.

80 The data is drawn from the Foundation Center's 2010 grants sample database, which includes all grants of $\$ 10,000$ or more awarded to organizations by a set of the top 1,000 foundations by total giving.

81 NCCS data show the Detroit metro with an 87 percent increase in nonprofit spending between 1990 and 2010, compared to a median of 138 percent for Midwest metros and $148 \%$ for the metros in our North category.

82 The average change in median household income between 1990 and 2010 was \$2,129. Tucson, Seattle, San Diego, and Denver experienced above average growth of $\$ 3,514, \$ 5,223, \$ 4,252$, and $\$ 4,788$, respectively. In contrast, median household income grew by only $\$ 438$ in St. Louis, and declined significantly in Detroit $(-\$ 4,894)$; U.S. Census Bureau 1990, 2009a, 2009b.

83 U.S. Census Bureau 2010.

84 U.S. Census Bureau 1992, 2012 a.

85 Frumkin 2009.

86 See Ramakrishnan and Bloemraad 2008 and De Graauw 2016.

87 U.S. Census Bureau 2002, 2012b.

88 U.S. Census Bureau 2014.

89 Erickson 2009.

90 Wardrip, Lambe, and de Zeeuw 2016, 51. 
91 Osili et al. 2013 cited in Wardrip, Lambe, and de Zeeuw; Pender 2015; on path dependence in patterns of philanthropy in the United States, see Duquette 2017.

92 Erickson 2009; Vidal 1992.

93 Katz and Bradley 2013, 88-112.

94 Morgan and Campbell 2011.

95 Ryan 2013, 37.

\section{References}

Adloff, Frank. 2006. "Religion and Social-Political Action: The Catholic Church, Catholic Charities, and the American Welfare State." International Review of Sociology [Revue internationale de sociologie]. 16(1): 1-30.

Alber, Jens. 1995. "A Framework for the Comparative Study of Social Services." Journal of European Social Policy. 5(2): 131-49.

Allard, Scott W. 2008. Out of Reach: Place, Poverty, and the New American Welfare State. New Haven, CT: Yale University Press.

Allard, Scott W. and Benjamin Roth. 2010. "Strained Suburbs: The Social Service Challenges of Rising Suburban Poverty." Washington, DC: Brookings Institution Metropolitan Policy Program.

Association of Religion Data Archives. 2010. U.S. Religion Census: Religious Congregations and Membership Study. Lenexa, KS: Association of Statisticians of American Religious Bodies.

Bailey, Martha J. and Nicolas J. Duquette. 2014. "How Johnson Fought the War on Poverty: The Economics and Politics of Funding at the Office of Economic Opportunity." Journal of Economic History 74(2): 351-88.

Berry, Jeffrey M., with David Aarons. 2003. A Voice for Nonprofits. Washington, DC: Brookings Institution Press.

Bielefeld, Wolfgang and William Suhs Cleveland. 2013. "Defining Faith-Based Organizations and Understanding Them through Research." Nonprofit and Voluntary Sector Quarterly 42(3): 442-67.

Bridges, Amy. 1999. Morning Glories: Municipal Reform in the Southwest. Princeton, NJ: Princeton University Press.

Brown, Dorothy M. and Elizabeth McKeown. 1997. The Poor Belong to Us: Catholic Charities and American Welfare. Cambridge, MA: Harvard University Press.

Bruch, Sarah K., Marcia Meyers, and Janet Gornick. 2016. "Separate and Unequal: The Dimensions and Consequences of Safety Net Decentralization in the U.S. 1994-2014." Institute for Research on Poverty. IRP Discussion Paper No. 1432-16. August. Madison: University of Wisconsin.

Burke, Colin B. 2001. "Nonprofit History's New Numbers (and the Need for More)." Nonprofit and Voluntary Sector Quarterly 30(2): 174-203.
Cammett, Melani and Lauren M. MacLean, eds. 2014. The Politics of Non-State Welfare. Ithaca, NY: Cornell University Press.

Chaves, Mark. 2001. "Religious Congregations and Welfare Reform." Society 38(2): 21-27.

Chaves, Mark and Alison Eagle, 2015. Religious Congregations in Twenty-First Century America. http://www. soc.duke.edu/natcong/Docs/NCSIII_report_final.pdf, accessed February 25, 2017.

Chaves, Mark and Lynn M. Higgins. 1992. "Comparing the Community Involvement of Black and White Congregations." Journal for the Scientific Study of Religion 31(4): 425-40.

Chaves, Mark, Laura Stephens, and Joseph Galaskiewicz. 2004. "Does Government Funding Suppress Nonprofits' Political Activity?" American Sociological Review 69(2): 292-316.

Chaves, Mark and William Tsitsos. 2001. "Congregations and Social Services: What They Do, How They Do It, and with Whom." Nonprofit and Voluntary Sector Quarterly 30(4): 660-83.

Chaves, Mark and Bob Wineburg. 2009. "Did the FaithBased Initiative Change Congregations?" Nonprofit and Voluntary Sector Quarterly, 39(2): 343-55.

Clemens, Elisabeth S. 2010. "In the Shadow of the New Deal: Reconfiguring the Roles of Government and Charity, 1928-1940." In Politics and Partnerships: The Role of Voluntary Associations in America's Political Past and Present, ed. Elisabeth S. Clemens and Doug Guthrie. Chicago: University of Chicago Press.

. 2017. "Reconciling Equal Treatment with Respect for Individuality: Associations in the Symbiotic State." In The Many Hands of the State: Theorizing Political Authority and Social Control, ed. Kimberly J. Morgan and Ann Shola Orloff. New York: Cambridge University Press.

De Graauw, Els. 2016. Making Immigrant Rights Real: Nonprofits and the Politics of Integration in San Francisco. Ithaca, NY: Cornell University Press.

Dowden-White, Priscilla A. 2011. Groping Toward Democracy: African American Social Welfare Reform in St. Louis, 1910-1949. Columbia: University of Missouri Press.

Duquette, Nicolas. 2017. "Inequality and Philanthropy: High-Income Giving in the United States 1917-2016." Available at SSRN, https://ssrn.com/abstract =3042802. Accessed August 12, 2017.

Ebaugh, Helen Rose, Janet Saltzman Chafetz, and Paula F. Pipes. 2006. "The Influence of Evangelicalism on Government Funding of Faith-Based Social Service Organizations." Review of Religious Research 47(4): 380-92.

Edin, Kathryn J. and H. Luke Shaefer. 2015. \$2.00 a Day: Living on Almost Nothing in America. Boston: Houghton Mifflin Harcourt. 
Erickson, David J. 2009. The Housing Policy Revolution: Networks and Neighborhoods. Washington, DC: Urban Institute Press.

Esping-Andersen, Gøsta. 1990. The Three Worlds of Welfare Capitalism. Princeton, NJ: Princeton University Press.

Ferguson, Karen Jane. 2002. Black Politics in New Deal Atlanta. Chapel Hill: University of North Carolina Press.

Fisher, Robert and Michael Fabricant. 2002. "From Henry Street to Contracted Services: Financing the Settlement House." Journal of Sociology and Social Welfare 29(3): 3-27.

Fox, Cybelle. 2012. Three Worlds of Relief: Race, Immigration, and the American Welfare State from the Progressive Era to the New Deal. Princeton, NJ: Princeton University Press.

Frumkin, Peter. 2009. On Being Nonprofit: A Conceptual and Policy Primer. Cambridge, MA: Harvard University Press.

Graddy, Elizabeth A. and Donald L. Morgan. 2006. "Community Foundations, Organizational Strategy, and Public Policy." Nonprofit and Voluntary Sector Quarterly 35(4): 605-30.

Grammich, Clifford, Kirk Hadaway, Richard Houseal, Dale E. Jones, Alexei Krindatch, Richie Stanley, and Richard H. Taylor. 2012. 2010 U.S. Religion Census: Religious Congregations and Membership Study. Lenexa, KS: Association of Statisticians of American Religious Bodies.

Grzymala-Busse, Anna. 2012. "Why Comparative Politics Should Take Religion (More) Seriously." Annual Review of Political Science 15: 421-42.

Hajnal, Zoltan L. and Jessica Trounstine. 2010. "Who or What Governs? The Effects of Economics, Politics, Institutions, and Needs on Local Spending." American Politics Research 38(6): 1130-63.

Hall, Peter Dobkin. 2006. "A Historical Overview of Philanthropy, Voluntary Associations, and Nonprofit Organizations in the United States, 1600-2000." In The Nonprofit Sector: A Research Handbook, 2nd ed., ed. Walter W. Powell and Richard Steinberg. New Haven, CT: Yale University Press.

Hammack, David C. 2017. "Nonprofit Organizations, "Philanthropy, and Civil Society." In A Companion to the Gilded Age and Progressive Era, ed. Christopher McKnight Nichols and Nancy C. Unger. Chichester, West Sussex: Wiley-Blackwell.

Hasenfeld, Yeheskel and Eve E. Garrow. 2012. "Nonprofit Human-Service Organizations, Social Rights, and Advocacy in a Neoliberal Welfare State." Social Service Review 86(2): 295-322.

Hero, Rodney E. and Robert Preuhs. 2006. "Multiculturalism and Welfare Policies in The USA: A State-Level Comparative Analysis." In Multiculturalism and the Welfare State: Recognition and Redistribution in Contemporary Democracies, ed. Keith Banting and Will Kymlicka. New York: Oxford University Press.

Hoge, Dean R. 1995. "Explanations for Current Levels of Religious Giving." In Cultures of Giving: How Region and Religion Influence Philanthropy, ed. Charles $\mathrm{H}$. Hamilton and Warren F. Ilchman. New Directions for Philanthropic Fundraising, San Francisco: Jossey-Bass Inc.

Howard, Christopher. 2007. The Welfare State Nobody Knows: Debunking Myths about U.S. Social Policy. Princeton, NJ: Princeton University Press.

Hyra, Derek S. 2008. The New Urban Renewal: The Economic Transformation of Harlem and Bronzeville. Chicago: University of Chicago Press.

Johnson, Kimberly. 2010. Reforming Jim Crow: Southern Politics and State in the Age Before Brown. New York: Oxford University Press.

Kahl, Sigrun. 2005. "The Religious Roots of Modern Poverty Policy: Catholic, Lutheran, and Reformed Protestant Traditions Compared." European Journal of Sociology [Archives européennes de sociologie/ /Europäisches archiv für soziologie]. 46(1): 91-126.

Katz, Michael B. 1987. In the Shadow of the Poorhouse. New York: Basic Books.

Katz, Bruce and Jennifer Bradley. 2013. The Metropolitan Revolution: How Cities and Metros Are Fixing Our Broken Politics and Fragile Economy. Washington, DC: Brookings Institution Press.

Katznelson, Ira. 1997. "Structure and Configuration in Comparative Politics.” In Comparative Politics: Rationality, Culture, and Structure, ed. Mark Irving Lichbach and Alan S. Zuckerman. New York: Cambridge University Press.

King, Desmond. 2017. "Forceful Federalism against American Racial Inequality." Government and Opposition 52(2): 356-82.

Lasch-Quinn, Elisabeth. 1993. Black Neighbors: Race and the Limits of Reform in the American Settlement House Movement, 1890-1945. Chapel Hill: University of North Carolina Press.

Lecy, Jesse D. and David M. Van Slyke. 2013. "Nonprofit Sector Growth and Density: Testing Theories of Government Support." Journal of Public Administration and Research and Theory 23(1): 189-214.

Lowry, Robert C. and Matthew Potoski. 2004. "Organized Interests and the Politics of Federal Discretionary Grants." Journal of Politics 66(2): 513-33.

Mahoney, James and Kathleen Thelen. 2010. "A Theory of Gradual Institutional Change.” In Explaining Institutional Change: Ambiguity, Agency, and Power, ed. James Mahoney and Kathleen Thelen. New York: Cambridge University Press.

McCarthy, John and Jim Castelli. 1999. ReligionSponsored Social Service Providers: The Not-So Independent Sector. Aspen Institute Working Paper 
Series. Washington, DC: Nonprofit Sector Research Fund.

Mettler, Suzanne. 1998. Dividing Citizens: Gender and Federalism in New Deal Public Policy. Ithaca, NY: Cornell University Press.

Morris, Andrew. 2004. "The Voluntary Sector's War on Poverty." Journal of Policy History. 16(4): 275-305.

Morgan, Kimberly J. 2006. Working Mothers and the Welfare State: Religion and the Politics of Work-Family Policies in Western Europe and the United States. Palo Alto, CA: Stanford University Press.

Morgan, Kimberly J. and Andrea Louise Campbell. 2011. The Delegated Welfare State: Medicare, Markets, and the Governance of Social Policy. New York: Oxford University Press.

Morgan, Kimberly J. and Ann Shola Orloff. 2017. "Introduction: The Many Hands of the State." In The Many Hands of the State: Theorizing Political Authority and Social Control, ed. Kimberly J. Morgan and Ann Shola Orloff. New York: Cambridge University Press.

Mosley, Jennifer E. 2010. "Organizational Resources and Environmental Incentives: Understanding the Policy Advocacy Involvement of Human Service Nonprofits." Social Service Review 84(1): 57-76.

National Center for Charitable Statistics. 1990. NCCS Core File Public Charities 1990. Washington, DC: Urban Institute.

- 2000. NCCS Core File Public Charities 2000.

Washington, DC: Urban Institute.

- 2010. NCCS Core File Public Charities 2010.

Washington, DC: Urban Institute.

Oates, Mary. 2003. "Faith and Good Works: Catholic Giving and Taking." In Charity, Philanthropy, and Civility in American History, ed. Lawrence J. Friedman and Mark D. McGarvie. New York: Cambridge University Press.

Orleck, Annelise and Lisa Gayle Hazirjian, eds. 2011. The War on Poverty: A New Grassroots History, 1964-1980. Athens: University of Georgia Press.

Osili, U., J. Ackerman, M. Copple, and Y. Li. 2013. Million Dollar Giving and Community Characteristics. Presented at the ARNOVA Conference, Hartford, CT, November 21.

Owens, Michael Leo. 2006. "Which Congregations Will Take Advantage of Charitable Choice? Explaining the Pursuit of Public Funding by Congregations." Social Science Quarterly 87(1): 55-75.

. 2008. God and Government in the Ghetto: The Politics of Church-State Collaboration in Black America. Chicago: University of Chicago Press.

Owens, Michael Leo and R. Drew Smith. 2005.

"Congregations in Low-Income Neighborhoods and the Implications for Social Welfare Policy Research." Nonprofit and Voluntary Sector Quarterly 34(3): 316-39.
Paarlberg, Laurie E. and Danielle M. Varda. 2009. "Community Carrying Capacity: A Network Perspective.” Nonprofit and Voluntary Sector Quarterly 38(4): 597-613.

Pender, John L. 2015. "Foundation Grants to Rural Areas From 2005 to 2010: Trends and Patterns." USDA Economic Research Service, Economic Information Bulletin 141. https://www.ers.usda.gov/webdocs/ publications/eib141/53165_eib141_summary.pdf, accessed February 26, 2017.

Pettijohn, Sarah L., Elizabeth T. Boris, Carol J. De Vita, and Saunji D. Fyffe. 2013. "Nonprofit-Government Contracts and Grants: Findings from the 2013 National Survey." Washington, DC: Urban Institute. http:// www.urban.org/research/publication/nonprofitgovernment-contracts-and-grants-findings-2013national-survey/view/full_report, accessed February 16, 2017.

Ramakrishnan, S. Karthick and Irene Bloemraad. 2008. Civic Hopes and Political Realities: Immigrants, Community Organizations, and Political Engagement. New York: Russell Sage Foundation.

Reckhow, Sarah. 2013. "The Delegated State and the Politics of Federal Grants." Presented at the Annual Meetings of the American Political Science Association, Chicago, August 29-September 1. https://papers.ssrn. com/sol3/papers.cfm?abstract_id $=2300594$ accessed February 26, 2017.

Reckhow, Sarah and Margaret Weir. 2012. "Building a Resilient Social Safety Net." In Building Resilient Regions. Vol. 4 of Urban and Regional Policy and Its Effects. Washington, DC: Brookings Institution Press.

Ryan, Paul 2012. The Path to Prosperity: A Blueprint for American Renewal. Fiscal Year 2013 Budget Resolution. Washington, DC: House Budget Committee.

Salamon, Lester M. 1987. "Of Market Failure, Voluntary Failure, and Third-Party Government: Toward a Theory of Government-Nonprofit Relations in the Modern Welfare State." Nonprofit and Voluntary Sector Quarterly 16(1-2): 29-49.

Salamon, Lester M. and Helmut K. Anheier. 1998. "Social Origins of Civil Society: Explaining the Nonprofit Sector Cross-Nationally." Voluntas: International Journal of Voluntary and Nonprofit Organizations 9(3): 21348.

Schäfer, Axel R. 2012. Piety and Public Funding: Evangelicals and the State in Modern America. Philadelphia: University of Pennsylvania Press.

Scheve, Kenneth and David Stasavage, 2006. "Religion and Preferences for Social Insurance." Quarterly Journal of Political Science 1(3): 255-86.

Shefter, Martin. 1983. "Regional Receptivity to Reform: The Legacy of the Progressive Era." Political Science Quarterly 98(3): 459-83. 
Smith, Steven Rathgeb. 2012. "Social Services." In The State of Nonprofit America, 2nd ed., ed. Lester M. Salamon. Washington, DC: Brookings Institution Press. Smith, Steven Rathgeb and Kirsten Grønbjerg. 2006 "Scope and Theory of Government-Nonprofit Relations." In The Nonprofit Sector: A Research Handbook Second Edition, ed. Walter W. Powell and Richard Steinberg. New Haven, CT: Yale University Press. Smith, Steven Rathgeb and Michael Lipsky. 1992. Nonprofits for Hire: The Welfare State in the Age of Contracting. Cambridge: Harvard University Press.

Snell, Kelsey and Mike DeBonis. 2016. "Ryan Unveils Anti-Poverty Proposal as Part of Election-Year Policy Agenda." Washington Post. June 7. https://www. washingtonpost.com/news/powerpost/wp/2016/06/ 07/ryan-to-unveil-poverty-agenda/?utm_ term $=.09036 \mathrm{~d} 9599 \mathrm{c} 8$, accessed January 16, 2017.

Soss, Joe, Richard C. Fording, and Sanford F. Schram. 2011. Disciplining the Poor: Neoliberal Paternalism and the Persistent Power of Race. Chicago: University of Chicago Press.

U.S. Census Bureau. 1990. Decennial Census, Summary File 3. Available at https://www.census.gov/main/www/ cen1990.html.

1992. 1992 Census of Governments. 1992 State and Local Government Finance. Washington, DC: U.S. Government Printing Office. Available at http://www2. census.gov/govs/local/92censusviewtabss.xls.

2002. Economic Census of the United States. Health

Care and Social Assistance: Geographic Area Series: Summary Statistics for the U.S., States, Metro Areas, Counties, and Places: https://www.census.gov/ programs-surveys/economic-census.html, accessed February 26, 2017.

2009a. "B01003: Total Population." 2005-2009

American Community Survey. Available at http:// factfinder2.census.gov.

2009b. "B1913: Median Household Income in the Past 12 Months." 2005-2009 American Community Survey. Available at http://factfinder2.census.gov.
2010. "Race, 2010" Prepared by Social Explorer. 2012a. 2012 Census of Governments. 2012 State

and Local Government Finance. Washington, DC: U.S. Government Printing Office. https://factfinder.census. gov/faces/tableservices/jsf/pages/productview.xhtml? pid=COG_2012_00A18prodType $=$ table.

. 2012b. Economic Census of the United States. Health Care and Social Assistance: Geographic Area Series: Summary Statistics for the U.S., States, Metro Areas, Counties, and Places: https://www.census.gov/ programs-surveys/economic-census.html, accessed February 26, 2017.

. 2014. Quarterly Workforce Indicators Data. Longitudinal-Employer Household Dynamics Program. http://lehd.ces.census.gov/data/\#qwi, accessed February 26, 2017.

Van Kersbergen, Kees and Philip Manow. 2009. Religion, Class Coalitions, and Welfare States. Cambridge: Cambridge University Press.

Vidal, Avis. 1992. Rebuilding Communities: A National Study of Urban Community Development Corporations. Community Development Research Center, Graduate School of Management and Urban Policy. New York: New School for Social Research.

Wardrip, Keith, William Lambe, and Mels de Zeeuw. 2016. "Following the Money: An Analysis of Foundation Grantmaking for Community and Economic Development." The Foundation Review 8(3): 51-65.

Weir, Margaret. 2005. "States, Race, and the Decline of New Deal Liberalism." Studies in American Political Development 19(2): 157-72.

Wilson, Charles Reagan. 2005. "Introduction: Preachin', Prayin', and Singin' on the Public Square." In Religion and Public Life in the South: In the Evangelical Mode, ed. Charles Reagan Wilson and Mark Silk. Walnut Creek, CA: Altamira Press.

Yerena, Anaid. 2015. "The Impact of Advocacy Organizations on Low-Income Housing Policy in US Cities." Urban Affairs Review 51(6): 843-70. 